Journal of Nepal Agricultural Research Council

Vol. 7: 122-132, April 2021

ISSN: 2392-4535 (Print), 2392-4543 (Online)

DOI: https://doi.org/10.3126/jnarc.v7i1.36934

A review

\title{
Conservation Agriculture Mitigates the Effects of Climate Change
}

Tika Bahadur Karki ${ }^{1}$ and Pankaj Gyawaly ${ }^{2}$

${ }^{1}$ Nepal Agricultural Research Council (NARC), Singhadurbar Plaza, Kathmandu, Nepal; @:

tbkarki2003@gmail.com

${ }^{2}$ National Agronomy Research Centre, Khumaltar, Lalitpur, Nepal

Received 23 July, 2020, Revised 12 Oct, 2020, Accepted 21 Jan, 2021, Published 30 April 2021

Scientific Editors: Amit Prasad Timilsina, Jiban Shrestha

Copyright $\odot 2020$ NARC. Permits unrestricted use, distribution and

reproduction in any medium provided the original work is properly cited.

The authors declare that there is no conflict of interest.

\section{ABSTRACT}

Intensive tillage based conventional agriculture have high global warming potential. Alternative to this, conservation agriculture (CA) systems utilize soils for the production of crops by reducing excessive tillage, maintaining crop residue on the soil surface, and adoption of crop rotations. The paper attempts to review the findings of CA based experiments under different cropping systems within and outside of the country. It has been found that CA increases and sustains the crop productivities, mitigates green house gas emissions from agriculture by enhancing soil carbon sequestration, improving soil nutrient status and water use efficiencies, and reducing fuel consumption. Mainstreaming of CA systems in Nepal is hindered by its knowledge gap, inadequate farm machineries and tools, small holdings, poor infrastructures, and lack of CA friendly policy support. Therefore, there is an urgent need to test, verify and scale-out the CA based technologies by Nepal Agricultural Research Council (NARC) across the different agro-ecologies through farmer-centered partnership among the international institutions, public and private sector of Nepal.

Keywords: Climate change, climate smart agriculture, conservation agriculture

\section{सारांश}

अधिक खनजोतमा आधारित पारम्परिक कृषिमा हरितगृह ग्याँस उत्शर्जन बढी हुन्छ। यसको विकल्पमा संरक्षण कृषि एक त्यस्तो प्रणाली हो जसमा कमसेकम खनजोत गरिन्छ, माटोको सतहमा अघिल्लो बालीको नल, पराल आदी छापोको रुपमा राखिन्छ भने बालीचक्रलाई ब्यबस्थित रुपमा उपयोग गरिन्छ। यो लेखमा देश भित्र र बाहिर विभित्र बाली प्रणालीहरुमा संरक्षण कृषि सम्बन्धि भए गरेका अध्ययन र अनुसन्धानका नतिजाहरूको समिक्षा गर्ने प्रयास गरिएको छ। अध्ययनको नतिजाले के देखाएको छ भने यसले बालीनालीहरुको उत्पादकत्वमा दिगो वृद्धि गराउँछ, माटोमा कार्बनको स्थिरिकरण बढाउँछ र हरितगृह ग्यासको उत्शर्जन घटाउँछ, माटोमा निहीत पोषकतत्वहरु र पानीको उपयोग क्षमतामा सुधार गर्दछ भने ईन्धनको कम खपत गर्दछ।यस सम्बन्धि ज्ञानको कमि, उपयुक्त कृषियन्त्रहरूको कमि, परम्परागत सोंच र संरक्षण कृषि मैत्री नीति नहुनाले यसलाई मुलधारको कृषि प्रणालीमा लैजान सकिएको। यसको लागि कृषक-केन्द्रित अनुसन्धानमा जोड दिनु पर्दछ र सोको लागि नार्कले बिभिन्न अन्तर्राष्ट्रिय निकायहरु र शार्वजनिक-निजी संस्थाहरुसंग समन्वय गरि विभिन्न कृषि पारिस्थितिकीय आवहवामा संरक्षण कृषिको परिक्षण, प्रमाणीकरण र क्षेत्र बिस्तार गरिनु पर्दछ।

\section{INTRODUCTION}

Conventional agriculture based on extensive tillage with removal or burning of crop residues have not only accelerated the soil erosion but also increased the greenhouse gas (GHG) emissions (Tomar et al 2019). Agriculture is considered as both cause and effect of greenhouse gas emissions, and it contributes to climate change both by anthropogenic emissions of greenhouse gases through faulty conventional agricultural practices and by the conversion of non-agricultural lands 
into agricultural land. Agriculture, forestry and land-use change contributed around 20 to $25 \%$ of global annual emissions in 2010 (IPCC 2010).

Open agricultural burnings mainly rice and wheat crop residues lead to huge nutrient loss besides deteriorating environment and human health (Singh et al 2019). The quantity of gases $\left(\mathrm{CH}_{4}, \mathrm{~N}_{2} \mathrm{O}\right.$, $\mathrm{SO}_{2}$, $\mathrm{CO}$ and $\mathrm{CO}_{2}$ ) released from agriculture contributes immensely to the global warming. Black carbon also helps in increasing the temperature thereby global warming and accelerate the melting of glaciers and snow in Himalayan region that destabilizes the weather pattern and alter the hydrological cycle. Also, some rare and useful biodiversities are also lost due to open agricultural burnings (Chao 2010).

Globally, climate change has impacted on rise of sea level (20 cm in the past 100 years), the world's glaciers will have disappeared in coming 100 years. Hurricanes, typhoons, droughts and prolonged heat waves will become common. Entire agro-ecosystems will change and agricultural pests, diseases and disease vectors will increase. The rising temperatures have been badly affecting the food security, for instance, the productivity of rice will decline by $10 \%$ with every $1^{\circ} \mathrm{C}$ increase in temperature (https://warmheartworldwide.org).

Moreover, the features of cause and effects of climate change in Nepal are similar to the rest of the world, since Nepal is less contributor but more vulnerable to it. However, we need an alternative agricultural system that is more likely to be climate smart. It is said that Climate Change impacting Nepal rather disproportionately compared to its size and its own meagre contribution of the greenhouse gases.

Considering the above facts, therefore CA based crop management practices across the various agro-ecologies need to be identified and promoted in Nepal too (Karki and Shrestha 2014a). Conservation agriculture practices can contribute to making agricultural systems more resilient to climate change. CA has been proven to reduce farming systems' greenhouse gas emissions and enhance their role as carbon sinks. Hence, the findings of a brief review of the CA based studies carried-out in different cropping systems within and outside the country has been presented in this article.

\section{Climate-Smart Agriculture (CSA)}

CSA is an evolving science and is understood by stakeholders in various ways. The Food and Agriculture Organization of the United Nations (FAO) defines CSA as "a way forward for food security in a changing climate. CSA aims to improve food security, help communities adapt to climate change and contribute to climate change mitigation by adopting appropriate practices, developing enabling policies and institutions and mobilizing needed finances" (FAO 2013). ADS (2015) has clearly indicated the promotion of green technologies and reduce carbon emissions in Nepal. Conceptually, there must be an integration of adaptation, mitigation and food security and thereby resulting outputs must be as indicated in Figure 1. It must be water, weather, knowledge, nutrient, carbon and energy smart in nature (Figure 2).

Conservation Agriculture seems to be one of the best production systems of CSA in mitigating the climate change effects, therefore, an attempt is made in this article to briefly review the past works done within and outside the country in the field of CA. The study was done mainly on CA and its effects on crop and systems yields, economics and status of major plant nutrients and organic matter in soil (Karki and Shrestha 2014b; Khatri and Karki 2015). 
Conceptual Framework for Climate-Smart Agriculture

\begin{tabular}{|c|c|}
\hline Integration of Policies & CSA Outputs \\
\hline Mitigation & $\begin{array}{ll}\text { - } & \text { Increse productivity } \\
\text { - } & \text { Increase net return } \\
\text { - } & \text { Improve input use efficiency } \\
\text { - } & \text { Reduction in emissions } \\
\text { - } & \text { Increse resilience } \\
\text { - } & \text { Increase gender and social inclusions }\end{array}$ \\
\hline
\end{tabular}

Figure 1. Conceptual framework for climate-smart agriculture (FAO 2010; Steenwerth et al 2014)

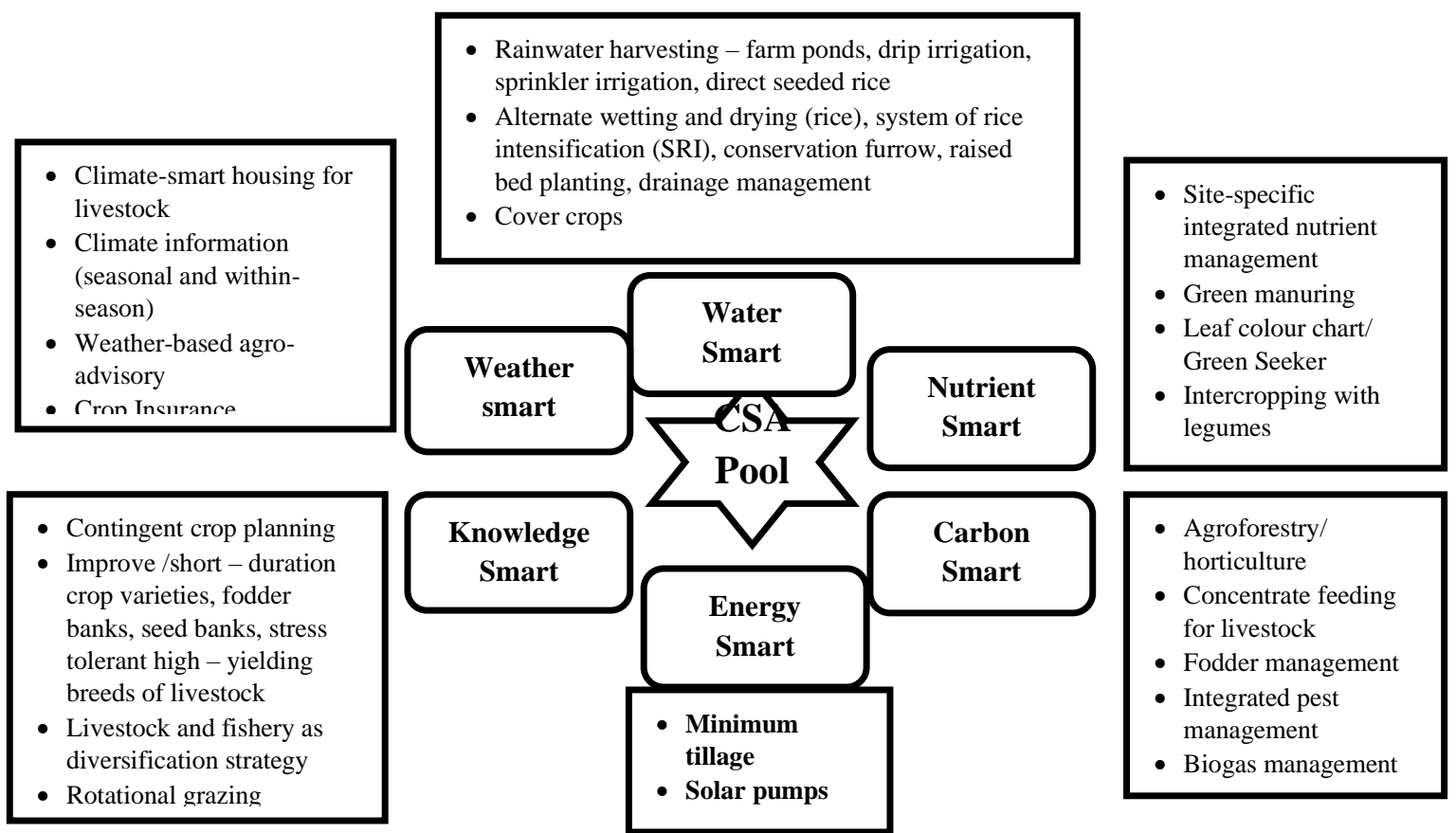

Figure 2. Pool of major CSA technologies and practices (Paudel et al 2017)

\section{What is Conservation Agriculture?}

FAO defines, Conservation Agriculture as a farming system that promotes maintenance of a permanent soil cover, minimum soil disturbance, and diversification of crop species. It enhances biodiversity, increase water and nutrient use efficiencies and improves and sustained crop production. CA promotes reverse degradation processes, improves resource quality, reduces production costs and helps achieve sustained high productivity. Global area under CA was about $180 \mathrm{M}$ ha, corresponding to about $12.5 \%$ of the total global crop land in 2015/16 (Kassam et al 2019).

\section{Conservation Agriculture and Climate Change}

CA based practices can contribute to significant quantities of atmospheric $\mathrm{CO}_{2}$ in the form of soil organic matter. CA reduces soil erosion, enhance infiltration, improve soil organic stocks and enhance soil quality in varied crops and environments, while reducing risks of soil degradation under rainfed conditions (Vlek and Tamene 2010). Similarly, CA practices can cause significant reduction in GHGs emissions through improved use efficiency of water and inputs and reducing fuel consumption (Drury et al 2012). Thus, it would appear that wider adoption of CA practices provides a win-win situation in meeting current challenges facing the agriculture sector. 


\section{CA and Crop Productivity}

FAO reported long-term crop yields are increased by CA resulting from increased soil fertility, reduced soil and water erosion, improved retention of water, nutrient and soil moisture across the globe (FAO 2010). In the first season of experiment, rice yield in direct seeded rice (DSR) was 5-10 $\%$ higher than conventionally tilled puddled transplanting rice (Marasini et al 2016). Similarly, grain yield of wheat was found to be increased by $6.28 \%$ in zero tillage over conventionally tillage method (Shrestha et al 2018). Gathala et al (2016) depicted that in a rice-wheat cropping system of SouthAsia, wheat yield was recorded $18 \%$ higher in zero tillage compared to conventional-tillage.

In Nepal, most of the studies have shown that the individual crop and system yields increased due to CA based practices. In a two years study carried out under maize based system in the hills revealed that the effect of no tillage and residue retention was evident over farmer's practice of conventional tillage without crop residues for crop yields of maize (Karki et al 2014). Similarly, in Terai, an experiment was carried out under rice-maize system, the system yield of maize during the first year was not obvious, however, was varied significantly in the second year and was $27.5 \%$ higher in CA over conventional agriculture (ConA) (Table 1).

Table 1. System yield $\left(\mathrm{kg} \mathrm{ha}^{-1}\right)$ of maize as influenced by establishment methods at Rampur, Chitwan, Nepal during 2010/11 and 2011/12.

\begin{tabular}{lcc} 
& \multicolumn{2}{c}{ System yield (kg ha $\left.{ }^{-\mathbf{1}}\right)$} \\
\cline { 2 - 3 } Treatments & \multicolumn{2}{c}{ Years } \\
\cline { 2 - 3 } & $\mathbf{2 0 1 0 / 1 1}$ & $\mathbf{2 0 1 1 / 1 2}$ \\
\hline Establishment methods & & 3943 \\
\hline ConA & 6234 & 5026 \\
\hline CA & 6234 & 73.3 \\
\hline SEM $( \pm)$ & 73.3 & 103.6 \\
\hline LSD $(0.05)$ & Ns & \\
\hline Sourc: Karki
\end{tabular}

Source: Karki et al (2014)

\section{CA and Economics}

\subsection{Economic Returns due to Carbon Sequestration}

Economic potential of $\mathrm{CA}$ for $\mathrm{C}$ sequestration considering the profitability and the cost of $\mathrm{C}$ sequestration, and the prospects for widespread adoption showed that generally, the off-site public benefits of CA exceed the on-farm private benefits. The initial cost of production may increase under $\mathrm{CA}$, but the gross margins and returns to labor are larger than conventional tillage. There are relatively few studies on the cost of $\mathrm{C}$ sequestration in our context; however, it seems that $\mathrm{C}$ sequestration through improved crop system management is competitive with non-agricultural $\mathrm{C}$ sequestration. Carbon markets offer the potential of additional income for farmers including, under certain conditions, smallholders in developing countries. The Clean Development Mechanism (CDM) of the Kyoto Protocol allows industrialized countries to invest in emission reductions wherever it is cheapest globally. The Kathmandu Post (16 $6^{\text {th }}$ January, 2016) wrote that recently, the $24^{\text {th }}$ board meeting of the green climate fund in Sangdo, South Korea has given the green signal to awarding a \$39.3million grant to the project titled 'Building Resilient Churia Region in Nepal.

\subsection{Economic Returns due to CA Based Practices}

Meta data analysis revealed that due to long-term yield increase and output stability along with reduced cost of production, the net profitability of the CA systems also increased (FAO 2010). In a dissertation study carried out by Karki et al (2016) at Rampur, found out that the combined gross return for both the years (2010/11 and 2011/12) was higher in CA over Conventional agriculture (ConA) (Table 2). 
Table 2. The combined gross return (NRs. ha ${ }^{-1}$ ) and benefit-cost ratio (BCR) as influenced by establishment methods at Rampur, Chitwan, Nepal, 2010/11 to 2011/12

\begin{tabular}{lcccc}
\hline \multirow{2}{*}{ Treatments } & \multicolumn{2}{c}{ Benefit cost ratio } & \multicolumn{2}{c}{ Gross return (NRs. ha $\left.\mathbf{~}^{-1}\right)$} \\
\cline { 2 - 5 } & $\mathbf{2 0 1 0 / 1 1}$ & $\mathbf{2 0 1 1 / 1 2}$ & $\mathbf{2 0 1 0 / 1 1}$ & $\mathbf{2 0 1 1 / 1 2}$ \\
\hline Establishment methods & & & & \\
\hline ConA & 1.47 & 1.13 & 232392 & 198998 \\
\hline CA & 1.58 & 1.35 & 244604 & 232185 \\
\hline SEM $( \pm)$ & 0.04 & 0.02 & 5387 & 4822.9 \\
\hline LSD $(0.05)$ & $\mathrm{ns}$ & 0.15 & 32779 & 29346.9 \\
\hline S & & & &
\end{tabular}

Source: Karki et al (2016)

\section{CA Reduces the Emissions of GHGs}

The carbon sink capacity of the world's agricultural and degraded soils is 50 to $60 \%$ of the historic carbon loss of 42 to 78 gigatons of carbon (Lal 2001). An increase of 1 ton of soil carbon pool may increase crop yields by $20-40 \mathrm{~kg} \mathrm{ha}^{-1}$ for wheat, and 10 to $20 \mathrm{~kg} \mathrm{ha}^{-1}$ for maize. Carbon sequestration has potential to offset fossil-fuel emissions by 0.4 to1.2 Giga tons of carbon/year, or 5 to $15 \%$ of the global fossil-fuel emissions (Lal 2003).

Organic matter is the principle $\mathrm{C}$ substrate for soil micro-organisms. Upon mineralization, some of the $\mathrm{C}$ in the organic material is used for growth and maintenance, while the remainder is respired as $\mathrm{CO}_{2}$ and returns to the atmosphere. As decomposition proceeds, the substrates which assimilate readily are rapidly metabolized whereas resistant compounds such as lignin substances tend to accumulate. Nutrient element deficiency at any stage of decomposition may limit microbial activity and thereby block nutrient release like N (Lavelle and Spain 2007).

\subsection{CA on Soill Organic Carbon Stocks and $\mathrm{CO}_{2}$ Emissions}

Soil organic carbon (SOC) stocks can be measured directly with soil samples or can be inferred via soil $\mathrm{CO}_{2}$ emissions (Batjes and Van 2015). Higher values for bulk density have been reported under zero tillage. Tillage practice can also influence the distribution of SOC in the profile with higher soil organic matter (SOM) content in the surface layers with zero tillage (ZT) than with conventional tillage, but a higher content of SOC in the deeper layers where residue is incorporated through tillage. In rice-wheat cropping system of Nepal, 22\% higher carbon content of soil in zero tilled residue retained plot was recorded over conventionally tilled plots (Paudel et al 2014). Similarly, in an experiment under rice-maize system of Terai, the soil organic matter was not varied during first and second season but was significantly varied in third and fourth season and was higher in CA over ConA (Figure 3). Changes in soil $\mathrm{C}$ can, in principle, be inferred from continuous measurements of net ecosystem $\mathrm{CO}_{2}$ exchange between the land surface and the atmosphere, provided other $\mathrm{C}$ additions or losses (e.g., harvested grain) are properly taken into account. Measurements of $\mathrm{CO}_{2}$ emissions have been confined mainly to the period after tillage events. To better understand the influence of the different components comprising CA (reduced tillage, crop residue retention, and crop rotation) on SOC stocks, we will discuss the effects of each of these components. With respect to greenhouse gas emissions, sustainable agricultural systems based on CA principles are described which result in lower emissions from farm operations as well as from machinery manufacturing processes, and that also help to reduce fertilizer use (Pisante et al 2015). 


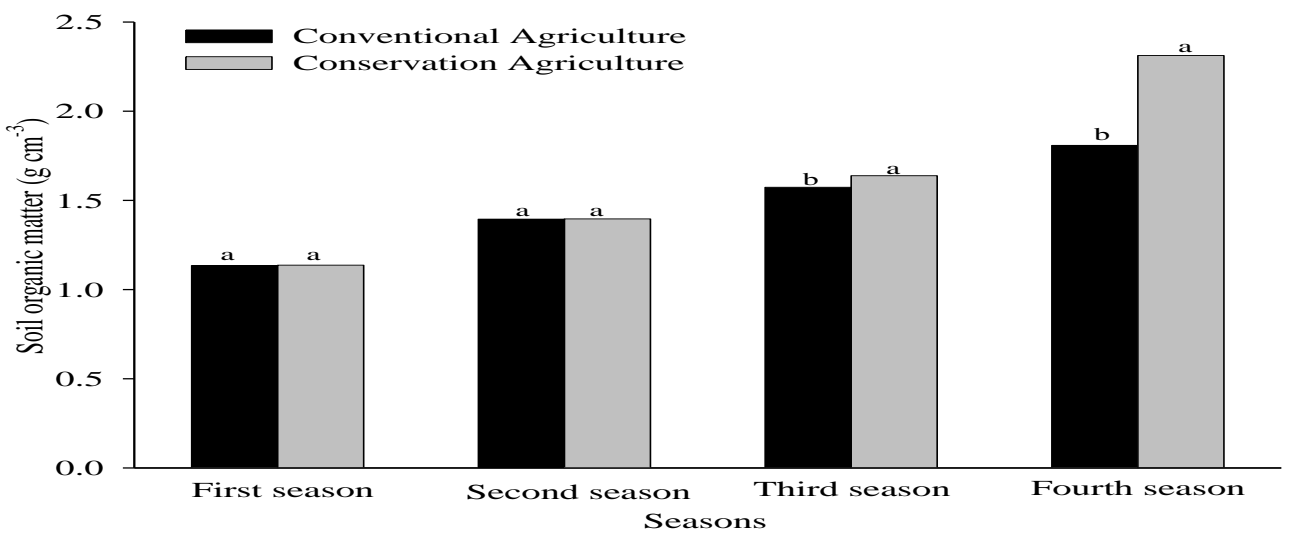

Figure 3. Soil organic matter as influenced by (A) establishment methods and (B) nutrient levels at Rampur, Chitwan, Nepal, 2010-2014

Source: Paudel et al (2014)

\subsection{Tillage and Soil Organic Carbon Stocks}

The influence of reduced tillage on SOC stocks is still to be explored. The mechanisms that govern the balance between increased or no sequestration after conversion to zero tillage are not clear. ZT can produce greater horizontal distribution of roots and greater root density near the surface. The effectiveness of $\mathrm{C}$ storage in $\mathrm{ZT}$ is reduced and can be negative when the baseline SOC content increases. It can be speculated that old depleted soils have more potential to sequester carbon compared to young soils rich in carbon. Soils that have lost SOC through soil erosion have a high potential to gain SOC when converted from conventional tillage to ZT. Management impacts are sensitive to climate in the following order from largest to smallest changes in SOC: tropical moist > tropical dry $>$ temperate moist $>$ temperate dry. Hence, the effects of tillage on soil carbon tend to be smaller or negative in cold temperate soils like in high Himalayan regions of Nepal.

In order to find out the effects of CA on soil organic matter (SOM) and nutrients, an experiment of tillage with two levels (NT: no till planting of maize and direct seeding of rice and CT: Conventional tillage for both the crops) and residue management with two levels (RK: Residue Kept i.e. maize residue anchored at $40 \mathrm{~cm}$ above the ground for rice planting and rice residue anchored at $30 \mathrm{~cm}$ for maize planting and RR: Residue Removed) under maize-rice system was carried out at Rampur, Chitwan, Nepal during 2010 to 2013. The effect of tillage and residue on the soil organic matter, N, $\mathrm{P}_{2} \mathrm{O}_{5}$ and $\mathrm{K}_{2} \mathrm{O}$ content was found to be significant. No tillage and residue kept plots had higher amount of soil organic matter, $\mathrm{N}, \mathrm{P}_{2} \mathrm{O}_{5}$ and $\mathrm{K}_{2} \mathrm{O}$ compared to conventionally tilled and residue removed plots (Table 3).

Table 3. Effect of tillage and residue methods on soil organic matter and chemical properties in rice field at Rampur, Chitwan, Nepal, 2010-2013.

\section{Treatments}

\begin{tabular}{lcccc}
\cline { 2 - 4 } & SOM\% & N\% & $\mathbf{P}_{\mathbf{2}} \mathbf{O}_{\mathbf{5}} \mathbf{~ k g ~ h a}{ }^{-\mathbf{1}}$ & $\mathbf{K}_{\mathbf{2}} \mathbf{O} \mathbf{~ k g ~ h a}^{\mathbf{- 1}}$ \\
\hline Tillage methods & & & & 93.3 \\
\hline Conventional tillage & 3.99 & 0.172 & 93.6 & 94.0 \\
\hline No tillage & 4.89 & 0.193 & 107.5 & 4.60 \\
\hline LSD (0.05) & 0.275 & 0.008 & 5.01 & 2.16 \\
\hline SEm \pm & 0.13 & 0.004 & 2.35 & 83.5 \\
\hline Residue management & & & & 103.8 \\
\hline Residue removed & 3.16 & 0.176 & 90.7 & 4.88 \\
\hline Residue kept & 5.72 & 0.190 & 5.31 & 2.29
\end{tabular}

Source: Karki and Shrestha (2015) 
Similarly, another experiment was conducted by the authors during 2010 to 2014 under rice-maize system at Rampur comparing no till with residues (CA) and conventional till without residue (ConA) for 4 years with 8 seasons to see the impacts on SOM. Interestingly, the effects were not obvious during the first two seasons, but the result was obvious after the $4^{\text {th }}$ season onward (Table 4). Therefore, in both the systems of Terai, Nepal, the effects of CA based treatments were evident for $\mathrm{SOM}\left(\mathrm{SOM}=\% \mathrm{SOC}^{*} 1.724\right)$. Experimental data from Henderson Research Station in Zimbabwe showed significantly greater soil carbon stocks in the $0-10 \mathrm{~cm}$ and $10-20 \mathrm{~cm}$ depth layers after only four years of different CA practices (Thierfelder et al 2012). Similarly, Cheesman et al (2016) revealed that there is a potential of increasing SOC in Sothern Africa after 7 years of CA based experiments.

Table 4. Soil organic matter as influenced by different establishment methods at Rampur, Chitwan, Nepal, 2010-2014

\begin{tabular}{lcccc}
\hline Treatment & $\mathbf{1}^{\text {st }}$ Season & $\mathbf{2}^{\text {nd }}$ Season & $\mathbf{4}^{\text {th }}$ Season & $\mathbf{8}^{\text {th }}$ Season \\
\hline Establishment methods & & & & \\
\hline ConA & 1.135 & 1.395 & 1.573 & 1.808 \\
\hline CA & 1.137 & 1.396 & 1.638 & 2.312 \\
\hline SEM $( \pm)$ & 0.001 & 0.005 & 0.007 & 0.014 \\
\hline LSD $(0.05)$ & $\mathrm{ns}$ & $\mathrm{ns}$ & 0.043 & 0.086
\end{tabular}

Source: Karki et al 2016

\subsection{Residue Retention and Soil Organic Carbon Stocks}

Crop residues are precursors of the SOM pool. The decomposition and assimilation of $\mathrm{C}$ through microbial biomass are the primary stages in the humus formation process. Returning more crop residue is associated with an increase in SOC concentration. The rate of decomposition depends not only on the amount of crop residues retained, but also on soil characteristics and the composition of residues (i.e., the soluble fraction, lignin, hemic cellulose and polyphenol content). It is directly related to C:N ratio of the crop by-products. Lignocellulosic biomass in general consists of 35\%$55 \%$ cellulose, $25 \%-40 \%$ hemicellulose, and $15 \%-25 \%$ lignin with small percentage of extractives, protein, and ash. Cellulose is generally considered to be more labile and is usually decomposed faster than lignin (Torres et al 2014) due to its chemical composition and structure (Dalal and Chan 2001).

In order to minimize open agricultural burnings, in-situ management of crop residues can be done by using no-till seeders such as Happy Seeder and by chopping or cutting and spreading the straw biomass at harvest. After applying a light irrigation to the harvested wheat field, summer moong/green manuring crops and maize fodder can be directly sown with the Happy Seeder in the standing wheat stubble (PAU 2019).

\subsection{Direct Seeded Rice (DSR) and GHG Emissions}

The net global warming potential (GWP) of methane $\left(\mathrm{CH}_{4}\right)$ and nitrous oxide $\left(\mathrm{N}_{2} \mathrm{O}\right)$ emissions were comparable between the two cropping systems of DSR and conventional transplanted rice (TPR), while the greenhouse gas intensity (GHGI) was significantly lower in the DSR than in the TPR cropping systems (Liu et al 2014). Ko JY (2000) also showed the higher emissions of methane gas in early transplanted rice than late transplanted DSR in China. Marasini et al (2016) also mentioned that Methane gas emissions were lower in DSR than with conventionally tilled transplanted puddle rice. A field experiment in the Philippines showed that the direct seeding techniques reduced methane emissions by $18 \%$ as compared with transplanted rice. Another study, in Japan, showed that global warming potential declined by $42 \%$ just by changing puddling of rice seedlings to zero tillage (Koirala 2016).

\section{Crop Rotation/Species Diversification}

Crop rotations not only offers a diverse "diet" to the soil micro-organisms, but also are capable of exploring different soil layers for nutrients. Deeper layer nutrients which are no longer available for the commercial crop can be "recycled" by the crops in rotation. This way the rotation crops function as biological pumps. Furthermore, it leads to a diverse soil flora and fauna, as the roots excrete different organic substances that attract different types of bacteria and fungi, which in turn, play an 
important role in the transformation of these substances into plant available nutrients. Crop rotation also has an important phyto-sanitary function as it prevents the carry-over of crop-specific pests and diseases from one crop to the next via crop residues (FAO 2017).

Firstly, design and implementation of crop rotations must be done according to the various objectives; food and fodder production (grain, leaf, stalks); residue production; pest and weed control; nutrient uptake and biological subsurface mixing/cultivation, etc. And secondly, use of appropriate / improved seeds for high yields as well as high residue production of above-ground and below-ground parts, given the soil and climate conditions.

\section{CA and Sustainability}

Agriculture in the next decade will have to sustainably produce more food from less land through more efficient use of natural resources and with minimal impact on the environment in order to meet growing population demands. Promoting and adopting CA management systems can help meet this goal (Hobbs et al 2007). Conservation agriculture has emerged as a new paradigm to achieve the goal of sustainable agricultural production. It is a major step for the transition of conventional agriculture to sustainable agriculture (Shrestha et al 2020). CA systems are sustainable in the longer run due to its suitability to different farming systems and agro-ecological domains. It is because of appropriate combinations of tillage, residue and crop rotation techniques, equipments and machines and inputs.

\section{Opportunities of CA}

Precision land leveling, no-till systems, furrow irrigated raised bed planting systems, crop residue management, crop diversification/rotations, green manuring and mulching, integrated pest management practices and précised weather fore-casting systems are some of the potential indicators of CA in Terai and plain areas of Nepal. Similarly, along with these, strip cropping, agro-forestry, contour farming, intercropping and crop rotation with legume species, high yielding crop varieties are few of the salient features of CA to be promoted in the hills.

NARC in collaboration with CIMMYT, IRRI and SRFSI has been working in CA since 1990s and has generated couple of CA based technologies and has learned its positive and negative consequences.

Country is in its federal system having three governments viz. federal, provincial and local. NARC as an apex body, has been working through its 62 different networks across the country. Similarly, department of agriculture/livestock/food technology and quality control under ministry of agriculture and livestock development along with some of the centrally governing bodies has been working in promoting the agricultural technologies. Seven provinces and 753 local level governments have also their agricultural development programs. Agricultural Universities and institutes have also their post graduate teaching and research programs of CA. An initiative has been already taken by forming a Conservation Agriculture and Sustainability Intensification (CASI) platform consisting of Bangladesh, India, Nepal and Pakistan to mutually assist and promote the CA based practices in IndoGangetic plains.

\section{Pathways for Adoption}

(1) Trade-offs between crop residues and animal feed: In areas where the crop residues are mainly fed to animals the other sources of plant biomass should be explored.

(2) Changing mindset: CA constitutes a major departure, and a paradigm shift from the way agriculture is being practiced conventionally. Bringing about a change in the mindset of all concerned; scientists, farmers and policy makers will call for persistent efforts aimed at creating awareness. Knowledge base common platform for researcher, farmers, extension workers and policy makers need to be formed. Each stakeholders needs to be aware of the scientific basis of $\mathrm{CA}$ and its evolution and growth.

(3) On-Station and on-farm research and demonstration: System based CA practices need to be generated in collaboration with CG systems and Universities under NARC stations (On-station) in 
comparison with the existing farmers practices. The technologies developed need to be further verified and demonstrated through Diamond Trials in farmer's field coordinated by NARC's outreach programs. A complete package of practices should be developed, verified and scaled-out in farmers led collaboration among researcher, extension workers, traders and policy makers. Most of the practices identified had adaptation or food security as an entry point, rather than mitigation; however, the identification of co-benefits and synergies between pillars gives smallholder farmers a role to play in emission reduction actions when considering their aggregated contributions (Martinez Baron et al 2018).

(4) Policy and institutional support: Wider adoption of CA practices will call for appropriate policy and institutional support at local, provincial and national level. As an example, maintaining residues on soil surface might call for incentives to encourage farmers to shift from current usage practice. CA practices bring benefit to the community as a whole by way of ecological and environmental improvements and for this reason, support to implementation of CA programs should be considered as part of environmental services.

(5) Networks of farmers group: Learning from farmer to farmer is the most functional pathway for further change in individual behavior. Sharing knowledge and experience across sites will be an important way to advance CA adoption. There is a need to organize knowledge networks using IT tools for greater information access and dissemination among the farmers-technicians and policy makers.

(6) Ensuring availability and access to machinery: A farmer-to-farmer CA service provision model is a preferred approach to enable smallholders' access to farm machinery. For this different set of equipment and system of custom hire services could also be a good approach in our situation. West Bengal government has made compulsory to have CA based machineries for operating the custom hiring centers in each village or production blocks (Tamara 2019) and that can be useful for us too.

\section{CONCLUSION}

The adoption of faulty conventional agricultural practices contributes to exacerbate the problem of global warming. There is a scope of mainstreaming CA as a means of CSA that minimize climate change effects, improves soil properties and food security. However, the key bottleneck is the knowledge gap mainly in conceptualization and execution of CA as CSA and policy implications across the globe. Generating scientific knowledge is a key factor to identify appropriate solutions to tackle climate change and scaling out the findings. Conservation agriculture is a cropping system characterized by both maximization of systems productivity and long-term sustainability. However, the key constraints need to be addressed if CA has to be applied as a CSA. Most studies have been done at the plot level, and more holistic research at the farm and community level across various agroecosystem is needed to generate the robust knowledge to bridge the gap. Therefore, there must be a strong functional collaboration among and between the various international and domestic actors working in the field of CA under the leadership of NARC.

\section{ACKNOWLEDGEMENT}

The authors are thankful to Nepal Agricultural Research Council, International Maize and Wheat Improvement Center (CIMMYT), International Rice Research Institute (IRRI) and Australian Centre of International Agricultural Research (ACIAR) involved in the field of CA and CSA within the country and across the globe.

\section{REFERENCES}

ADS. 2015. Agricultural Development Strategy (2015-2025). Government of Nepal, Ministry of Agricultural Development, Singhadurbar, Kathmandu, Nepal.

Batjes NH and WB Van. 2015. Measuring and monitoring soil carbon. In S. A. Banwart, E. Noelmeyer, \& E. Milne (Eds.), Soil carbon: Science, management and policy for multiple benefits. pp.188-201. Wallingford, UK: CABI.

Chao J. 2010. Black carbon a significant factor in melting of himalayan glaciers. Feature Story Julie Chao 510486-6491. Berkley Lab. University of California, USA

Cheesman S, T Christian, SE Neal, TK Girma and F Emmanuel. 2016. Soil carbon stocks in conservation agriculture systems of Southern Africa. Soil and Tillage Research 156:99-109. 
Dalal R and K Chan. 2001. Soil organic matter in rainfed cropping systems of the Australian cereal belt. Soil Res. 39: 435 .

Drury CF, WD Reynolds, XM Yang, TW Welacky, NB McLaughlin, W Calder and CA Grant. 2012. Nitrogen source, application time and tillage effects on soil N2O emissions and corn grain yields. Journal of Soil Science Society of America 76:1268-1279.

FAO. 2010. Conservation Agriculture and Sustainable Crop Intensification in Lesotho. Integrated Crop Management. 10:59.

FAO. 2013. Rome: Food and Agriculture Organization of the United Nations (www.fao.org/docrep/018/i3325e/i3325e.pdf)

FAO. 2017. Conservation Agriculture-Revised Version. Ag. Dept. Factsheet. Food and Agriculture Organization. Rome, Italy.

Gathala MK, J K Ladha, V Kumar, YS Saharawat, V Kumar, PK Sharma, S Sharma and H Pathak. 2011. Tillage and Crop Establishment Affects Sustainability of South Asian Rice-Wheat System. Agronomy J. 103 (4): 961-971.

Hobbs PR, K. Sayre and R Gupta. 2007. The role of conservation agriculture in sustainable agriculture Phil. Trans. R. Soc. B363543-555 DOI: http://doi.org/10.1098/rstb.2007.2169.

Karki TB and J Shrestha. 2014a. Conservation agriculture: significance, challenges and opportunities in Nepal. J. Plants Agric. Res. 1(5):186-188.

Karki TB and J Shrestha. 2014b. Maize Production under no-tillage system in Nepal. World Journal of Agricultural Research. 2 (6A): 13-17.

Karki TB and J Shrestha. 2015. Tillage Affects the Soil Properties and Crop Yields. Proceedings of the workshop (24-25 March, 2015): pp 432-438.

Karki TB, N Gadal and J Shrestha. 2014. Studies on the Conservation Agriculture Based Practices under Maize (Zea mays L.) Based System in the Hills of Nepal. Int J of Applied Sciences and Biotechnology 2(2):185192. DOI: https://doi.org/10.3126/ijasbt.v2i2.10353

Kassam A, T Friedrich and R Derpsch. 2019. Global spread of Conservation Agriculture, International Journal of Environmental Studies 76(1): 29-51, DOI: https://10.1080/00207233.2018.1494927

Khatri N and TB Karki. 2015. Economics and agronomic performance of maize and soybean intercropping under various tillage and residue level. American Journal of Agronomy 2 (4): 81-86

Ko JY and Kang HW. 2000. The effects of cultural practices on methane emission from rice fields. Nutr Cycl Agroecosyst. 58:311-314

Koirala S. 2016. Rice paddies raise methane threat. Climate news Network.

Lavelle, P and Spain, A. 2007. Soil Ecology. Springer Science and Business Media.

Lal R. 2001. Soil organic carbon pools and sequestration rates in reclaimed minesoils in Ohio. Adv. Agron. (71): 145

Lal R. 2003. Global potential of soil carbon sequestration to mitigate the greenhouse effect. Critical Reviews in Plant Sciences 22(2):151-184

Liu S, Y Zhang, F Lin, L Zhang and J Zou. 2014. Methane and nitrous oxide emissions from direct-seeded and seedling-transplanted rice paddies in southeast China. Plant and Soil 374 (1-2): 285-297.

Marasini S, T Joshi and LP Amgain. 2016. Direct seeded rice cultivation method: a new technology for climate change and food security. Journal of Agriculture and Environment 17: 30-38.

Martinez-Baron, D. (2016). Análisis del cambio institucional en la zona rural noroccidental de Popayán en un contexto de variabilidad climática. Master thesis on Rural Development, Pontificia Javeriana University. Bogotá, Colombia.

PAU. 2019. Package of practices for crops of Punjab. Rabi-2019-20. Punjab Agricultural University, Punjab: 36 (2).

Paudel M, SK Sah, AJ McDonald and NK Chaudhary. 2014. Soil Organic Carbon Sequestration in Rice-Wheat System under Conservation and Conventional Agriculture in Western Chitwan, Nepal." World Journal of Agricultural Research 2(6A):1-5. DOI: https://10.12691/wjar-2-6A-1.

Paudel B, RC Khanai, A KC, K Bhatta and P Chaudhary. 2017. Climate-smart agriculture in Nepal. Championing technologies and their pathways for scaling-up.

Pisante M, F Stagnari, M Acutis, M Bindi, L Brilli, VDi Stefano and M Carozi. 2015. Conservation Agriculture and Climate Change. In: Conservation Agriculture. Agronomy and Crop Sciences Research and Education Center, Italy; pp. 579-620.

Shrestha J, Subedi S, Timsina KP, Chaudhary A, Kandel MA and Tripathi S. 2020. Conservation agriculture as an approach towards sustainable crop production: A review. Farming and Management 5:7-15.

Shrestha KP, R Giri, S Kafle, R Chaudhary and J Shrestha. 2018. Zero tillage impacts on economics of wheat production in far western Nepal. Fmg. \& Mngmt. 3(2): 93-99. 
Singh R, DB Yadav, N Ravishankar, A Yadav and HP Singh. 2019. Crop residue management in rice-wheat cropping system for resource conservation and environmental protection in north-western India. Environment, Development and Sustainability 22: 3871-3896.

Steenwerth, KL, AK Hodson, AJBloom, MRCarter, ACattaneo, CJChartres, JLHatfield, KHenry, JWHopmans, WRHorwath, BM Jenkins, EKebreab, RLeemans, L Lipper, MN Lubell, SMsangi, RPrabhu, MPReynolds, SSSoils, WM Sischo, M Springborn, PTittonell, SMWheeler, SJVermeulen, EKWollenberg, LSJarvis and LEJackson. 2014. Climate-Smart Agriculture Global Research Agenda: Scientific Basis for Action. Agriculture and Food Security 3(11): 1-39

Tamara J. 2019. CA machinery now a compulsory part of Custom Hiring Centres in West Bengal. ACIAR.SDIP. Australia.

Thierfelder C, S Cheesman and L Rusinamhodzi. 2012. A comparative analysis of conservation agriculture systems: Benefits and challenges of rotations and intercropping in Zimbabwe. Field Crop Res. 137: $237-$ 250

Tomar SK, NC Mahajan, SN Singh, V Kumar and RK Naresh. 2019. Conservation Tillage and Residue Management towards Low Greenhouse Gas Emission; Storage and Turnover of Natural Organic Matter in Soil under Sub-tropical Ecosystems: A Review. Int. J. Curr. Microbiol. App. Sci. 8(4): 2211-2231.

Torres IF, C García, F Bastida, HH Richnow, P Bombach, H Hernández. 2014. The role of lignin and cellulose in the carbon-cycling of degraded soils under semiarid climate and their relation to microbial biomass. Soil Biol Biochem. 75, 152-160.

Vlek L and GP Tamene. 2010. Conservation agriculture: why? Conservation Agriculture: Innovations for Improving Efficiency, Equity and Environment. National Academy of Agricultural Sciences (NAAS), NASC Complex, DPS, Marg, New Delhi, India: pp. 89-100.

weADAPT@, 2007. Building Capacity on Climate Adaptation. Stockholm Environment Institute.www.sei.org.<smiles>[AlH]=[AlH]</smiles> 